\title{
Alpha-Fetoprotein産生腺癌と扁平上皮癌からなる 肺衝突癌の一切除例
}

\author{
A Case of Collision Tumor of Alpha-Fetoprotein Producing Adenocarcinoma \\ and Squamous Cell Carcinoma of the Lung
}

横井香平・宮沢直人・森 清志・富永慶晤・鈴木恵子*・島村香也子*

要旨：72才男性, 左上葉肺癌症例で, 35年前の右胸郭形成術による低肺機能と腫瘍の縦隔進展 の診断のもとに, 原発巣に放射線治療を $12 \mathrm{~Gy}$ 受けた. 当院に転院後, 腫瘍の縦隔進展に ついてpneumothorax CTにより再評価し, 呼吸機能からも左上区域切除術が可能と判断 し手術を施行した。術前血清AFPが $5107 \mathrm{ng} / \mathrm{ml}$ と高值を示し, 免疫組織化学的に低分化 腺管型腺癌細胞内にAFPの局在を証明し得た。また本腫瘍は低分化腺管型腺癌と中分化 扁平上皮癌からなる衝突癌であった。

〔肺癌 29(1)：75〜81，1989〕

Key words : AFP-producing lung cancer, Collision tumor, Pneumothorax CT.

\section{はじめに}

Alpha-fetoprotein(以下AFPと略す)は腫瘍 マ一カーとして原発性肝癌, 卵黄囊癌, 覀性奇 形腫などの診断，治療に有用であるが，近年原 発性肺癌症例においても血清AFPが高值を示

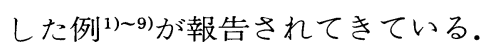

我々は35年前に右胸郭形成術を受け，その経 過観察中に左肺上葉に発生したAFP産生低分 化腺管型腺癌と中分化扁平上皮癌の衝突癌と考 えられた症例を経験したので報告する。

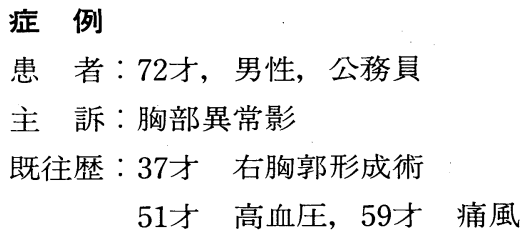

栃木県立がんセンター呼吸器科

$*$

同病理
家族歴：妹 2 人が肺癌に罹患

現病歴: 右胸郭形成術の経過観察中, 1986年 10 月胸部異常影を指摘され某病院を紹介され, TBLBにより扁平上皮癌と診断された.CT等よ り大動脈弓への癌浸潤および腫瘍に連続した縦 隔リンパ節転移が疑われたことと, 右胸郭形成 術のために肺機能が低下していることから手術 不能と判断され，原発巣に放射線治療が行われ た. $12 \mathrm{~Gy}$ 照射後，当院に転院した．契煙歴は60 本/日，50年間，Brinkmann Index 3000であっ た。

入院時現症：身長 $160 \mathrm{~cm}$ ，体重 $55.5 \mathrm{~kg}$ ，血圧 $140 / 78 \mathrm{mmHg}$, 脈拍 $60 /$ 分, 整. 貧血, 黄疸等な く，表在リンパ節は触知されなかった，右胸郭 に変形を認めたが，心，呼吸音は正常であった。 肝脾腫はなく，睪丸も正常であった。

入院時検查所見 (Table 1)：白血球の軽度減 少と赤沈值の亢進を認めたが, 肝機能, 腎機能 
Table 1. Laboratory findings.

\begin{tabular}{|c|c|c|c|}
\hline WBC & $2900 / \mathrm{mm}^{3}$ & $\mathrm{AFP}$ & $5107 \mathrm{ng} / \mathrm{m} l$ \\
\hline $\mathrm{RBC}$ & $409 \times 10^{4} / \mathrm{mm}^{3}$ & CEA & $12.8 \mathrm{ng} / \mathrm{ml}$ \\
\hline $\mathrm{Hb}$ & $12.9 \mathrm{~g} / \mathrm{d} l$ & CA19-9 & $11.6 \mathrm{U} / \mathrm{m} l$ \\
\hline $\mathrm{Ht}$ & $39.6 \%$ & $\mathrm{SCC}$ & $<1.5 \mathrm{ng} / \mathrm{m} l$ \\
\hline Plt & $21.0 \times 10^{4} / \mathrm{mm}^{8}$ & & \\
\hline \multirow[t]{2}{*}{ ESR } & $52 \mathrm{~mm}$ & $\mathrm{PaO}_{2}$ & 69.5 torr \\
\hline & & $\mathrm{PaCO}_{2}$ & 41.3 torr \\
\hline TP & $7.3 \mathrm{~g} / \mathrm{d} l$ & $\mathrm{VC}$ & $2290 \mathrm{ml}$ \\
\hline ALB & $54.7 \%$ & $\% \mathrm{VC}$ & $73.2 \%$ \\
\hline$\alpha_{1}$ & $4.2 \%$ & $\mathrm{FEV}_{1.0}$ & $1490 \mathrm{~m} l$ \\
\hline$\beta$ & $12.7 \%$ & $\mathrm{FEV}_{1.0 \%}$ & $69.0 \%$ \\
\hline$\gamma$ & $14.4 \%$ & MVV & $44.0 \mathrm{l} / \mathrm{min}$ \\
\hline GOT & $16 \mathrm{U} / \ell$ & $\% \mathrm{MVV}$ & $56.9 \%$ \\
\hline GPT & $11 \mathrm{U} / \ell$ & & \\
\hline $\mathrm{LDH}$ & $348 \mathrm{U} / \ell$ & ECG & WPW syndrome \\
\hline ALP & $79 \mathrm{U} / \ell$ & & Master test $(+)$ \\
\hline $\mathrm{CH}-\mathrm{E}$ & $296 \mathrm{U} / \ell$ & & \\
\hline LAP & $30 \mathrm{U} / \ell$ & Sputum & Squamous cell \\
\hline$\gamma-\mathrm{GTP}$ & $25 \mathrm{U} / \ell$ & cytology & y carcinoma \\
\hline BUN & $16.3 \mathrm{mg} / \mathrm{d} l$ & & \\
\hline $\mathrm{Cr}$ & $0.7 \mathrm{mg} / \mathrm{d} l$ & & \\
\hline $\mathrm{US}$ & $(-)$ & & \\
\hline U Prot & $(-)$ & & \\
\hline
\end{tabular}

には異常を認めなかった。腫瘍マーカーは, 血 清 $\mathrm{AFP}$ か $5107 \mathrm{ng} / \mathrm{ml}$ 異常高值を示し, 血清 CEAも $12.8 \mathrm{ng} / \mathrm{ml}$ と高値を示した。喀痰細胞診 では扁平上皮癌細胞が検出された。呼吸機能は 軽度の混合性換気障害を示し, 最大換気率の低 下も認施れた。心電図上WPW症候群を認め, 負荷試験で虚血性変化が見られた。

画像診断：Fig. 1は入院時胸部 X線写真であ る. 右胸郭形成術のため第 1 肋骨から第 7 肋骨 までが切除されている。腫瘍は左肺上葉 $\mathrm{S}^{3}$ 及び $\mathrm{S}^{1+2}$ の領域で大動脈弓上方に存在し, 大動脈々 の境界は不明瞭である。また腫瘍陰影周囲には 石灰化像を認めた。

断層写真 (Fig. 2)に招いても大動脈弓外上方 に存在する腫瘍と, 大動脈との境界は不明瞭で あった。なお腫瘤外側の石灰化像のやや肺尖側 に辺緑不明瞭な異常陰影が認められた。

アンギオグラフィンで行ったenhanced CT (Fig. 3a)に扔いても, 腫瘍は大動脈弓最上部か
Fig. 1. Chest X-ray film on admission, shows a tumor mass in the left upper lung field.

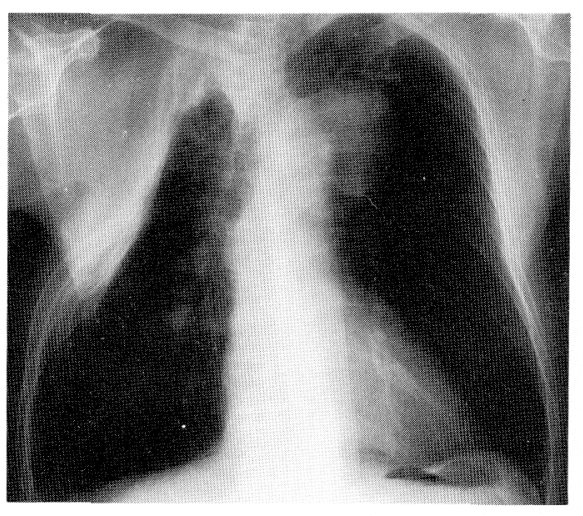

Fig. 2. Chest tomograms show the tumor in left $\mathrm{S}^{3}$ and $\mathrm{S}^{1+2}$ appeared in contact with the aorta. An abnormal shadow can be seen in the left apex of the lung.
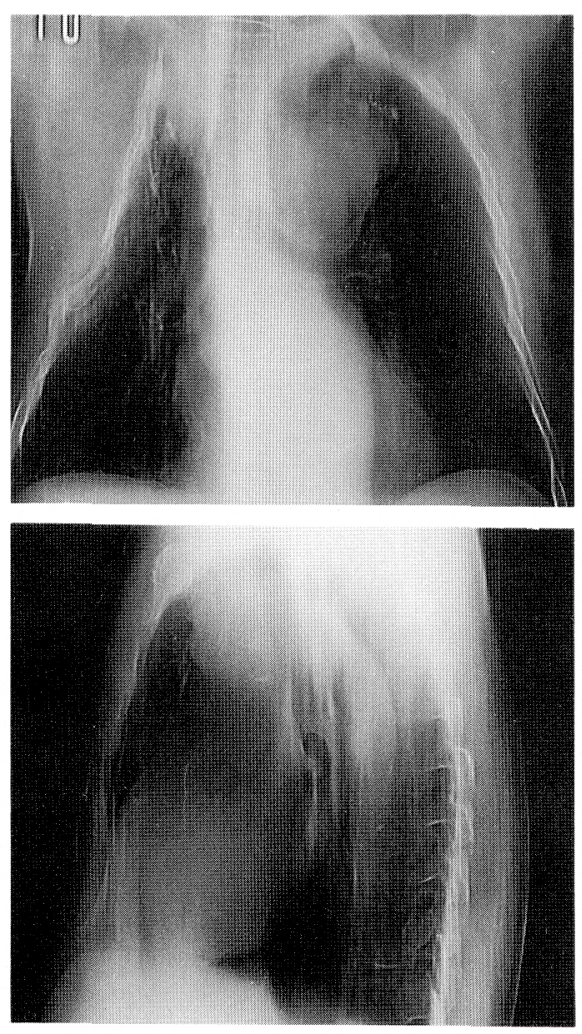

ら弓部全体にかけて大動脈と接して存在し, 腫 瘍と大動脈との間のlow density zoneは認めら れず，大動脈浸潤は否定できなかった。しかし 
Fig. 3. The tumor shadow is not separated from the aortic wall in the enhanced CT scan (a) but a definite air space between them can be seen on pneumothorax CT scan (b).

a)

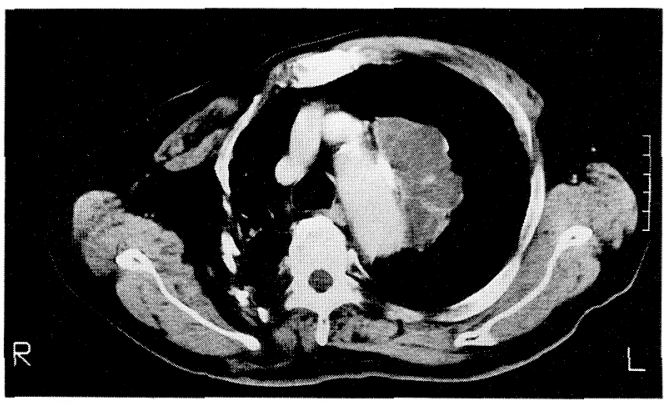

b)

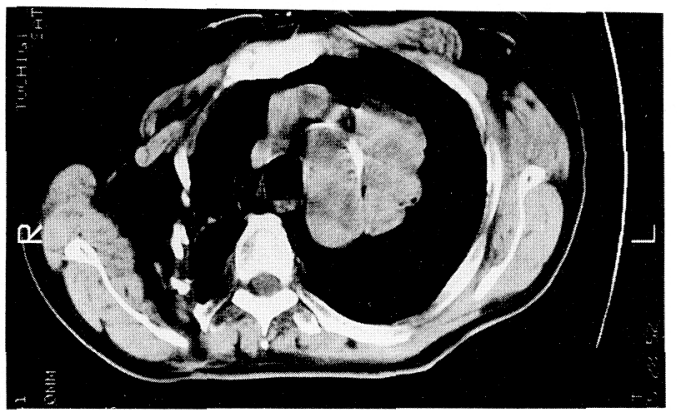

胸腔内に約 $200 \mathrm{ml}$ の空気を注入後撮影した pneumothorax $\mathrm{CT}^{10)}$ (Fig. 3b)では, 大動脈弓 と腫瘍との間に明らかに間隙が見られ，大動脈 壁への浸潤はないと判定された。なお腹部エコ 一では肝臓に異常を認めなかった。

以上より $\mathrm{c}-\mathrm{T} 2 \mathrm{~N} 0 \mathrm{M} 0$ の $\mathrm{AFP}$ 産生肺扁平上皮 癌と診断し, 左上区域切除術を施行した。

手術所見：腫瘍は主に $\mathrm{S}^{3}$ から $\mathrm{S}^{1+2}$ に存在し, 縦隔，肺門のリンパ節腫大は認めなかった。左 上区域切除術を行い，腫瘍の浸潤が疑われた $\mathrm{S}^{6}$ の一部とその周囲の壁側胸膜の一部を合併切除 した。な扮左上葉と大動脈弓との間は術前評価 の通り，軽度の線維性療着があるのみであった。

病理学的所見：Fig. 4は腫瘍の最大割面であ る.腫瘍は $\mathrm{B}^{1+z} \mathrm{~b}$ を閉塞し, $\mathrm{S}^{1+2} \mathrm{~b}$ に限局する直径 $7 \mathrm{~cm}$ 大の結節 (左方) とその外側の $\mathrm{S}^{1+2} \mathrm{~b}$ を中心 に $\mathrm{S}^{6}$ 抢よび壁側胸膜に浸潤した直径 $2.5 \mathrm{~cm}$ 大の 結節 (右方)より成り，両者は矢印の部分で小葉 間結合織を境に明瞭に区別され，組織学的にも 腺癌 (左方) と扁平上皮癌 (右方) の衝突癌之診断
Fig. 4. The resected specimen contains a large tumor (left side) and a small tumor (right side). These two tumors collide with each other in a small area (arrow).

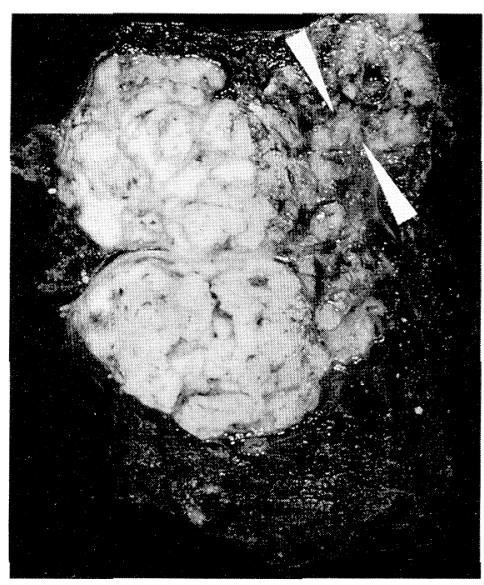

Fig. 5. Two different histologies are in contact with each other independently and separated by interlobular connective tissue (arrow). (H.E. $\times 10)$

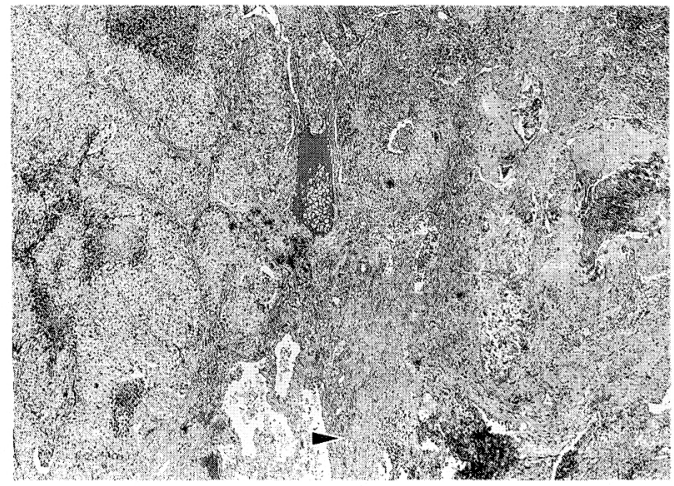

された(Fig. 5)。大きい方の腫瘍は分葉状で圧 排性増殖を示寸低分化腺管型腺癌 (Fig. 6a) で, 大部分が壊死に陥っており，一部に腺腔形成を 示す部分が見られた。癌細胞は細胞質が豊富で やや淡明であり，PAS，Alcian blue染色ではと もに陰性であった。一部の癌細胞内および腺腔 内に好酸性硝子体を認めた (Fig. 6b).一方小さ い方の腫瘍は, 線維化と炭粉沈着を伴う辺縁不 明瞭な腫瘍で，組織学的には癌真珠を認める中 分化扁平上皮癌であった(Fig. 7)。両者の衝突 部の近傍には, 石灰化を伴った結核結節が認め 
Fig. 6. a: The large tumor shows poorly differentiated tubular adenocarcinoma. (H.E. $\times 33$ ) $\mathrm{b}$ : Eosinophilic hyaline droplets are noted in the tumor cells and in the intercellular spaces of the adenocarcinoma (PAS, $\times 100)$

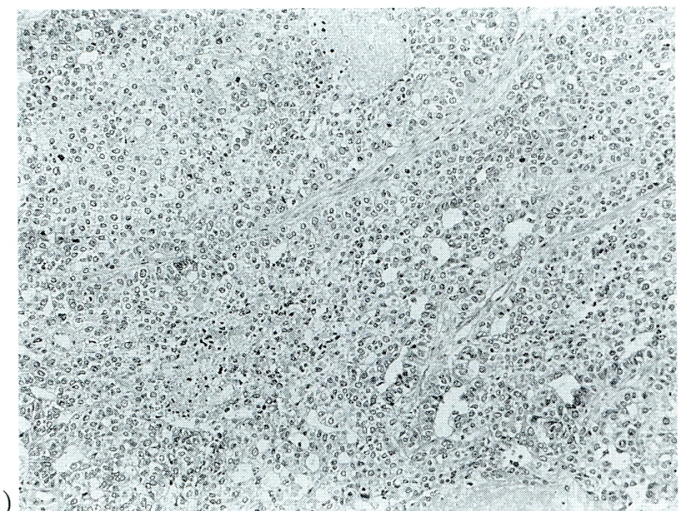

a)

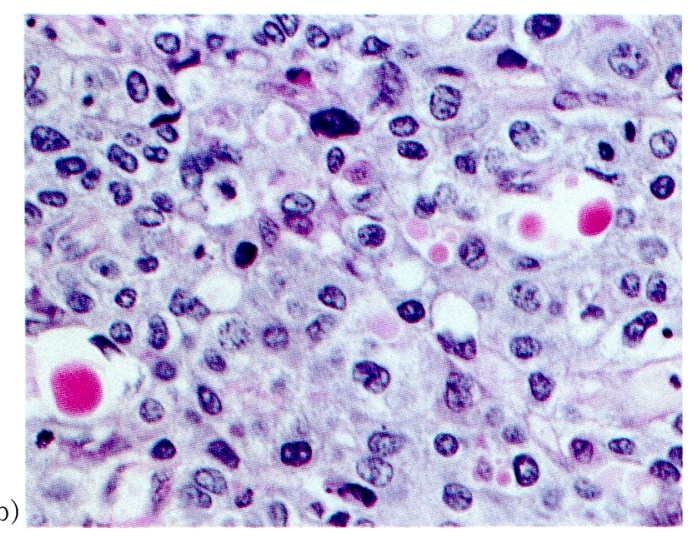

られた。な掞リンパ節転移は認められなかった。 免疫組織化学的に $\mathrm{ABC}$ 法を用いて $\mathrm{AFP}$ と CEAの局在を検索した。抗AFP抗体(Biogenex Lab.)により一部の腺癌細胞が陽性を示し(Fig. 8a), 抗CEA抗体(IBL社)により腫瘍辺縁に見 られた腺腔形成を示军腺癌細胞が強陽性に染色 された (Fig. 8b)。また扁平上皮癌細胞や好酸性 硝子体ではいずれも陰性であった。

術後経過：術後, 労作時の動悸と呼吸困難が 2 个月ほど続いたが, その後は運動量も増加し 日常生活に支障なく過ごしている。腫場マーカ 一については血清CEAが術後 8 日目に4.0ng/ $\mathrm{ml}$, 血清AFPが34日目に $13.1 \mathrm{ng} / \mathrm{ml}$ と正常值域 に下降した。16ケ月を経た現在再発の徵候, 腫 瘍マーカーの再上昇は認めていない.
Fig. 7. The small tumor was moderately differentiated squamous cell carcinoma. (H.E. $\times$ 33)

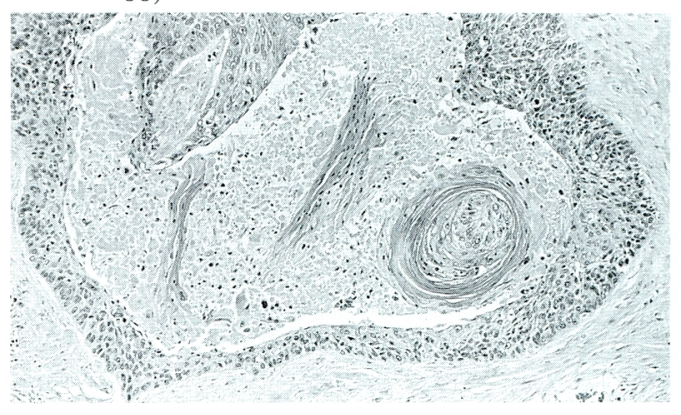

Fig. 8. Some adenocarcinoma tumor cells are stained with anti-AFP serum (a, ABC method, $\times 100)$ and anti-CEA serum $(b, A B C$ method, $\times 66$ ).
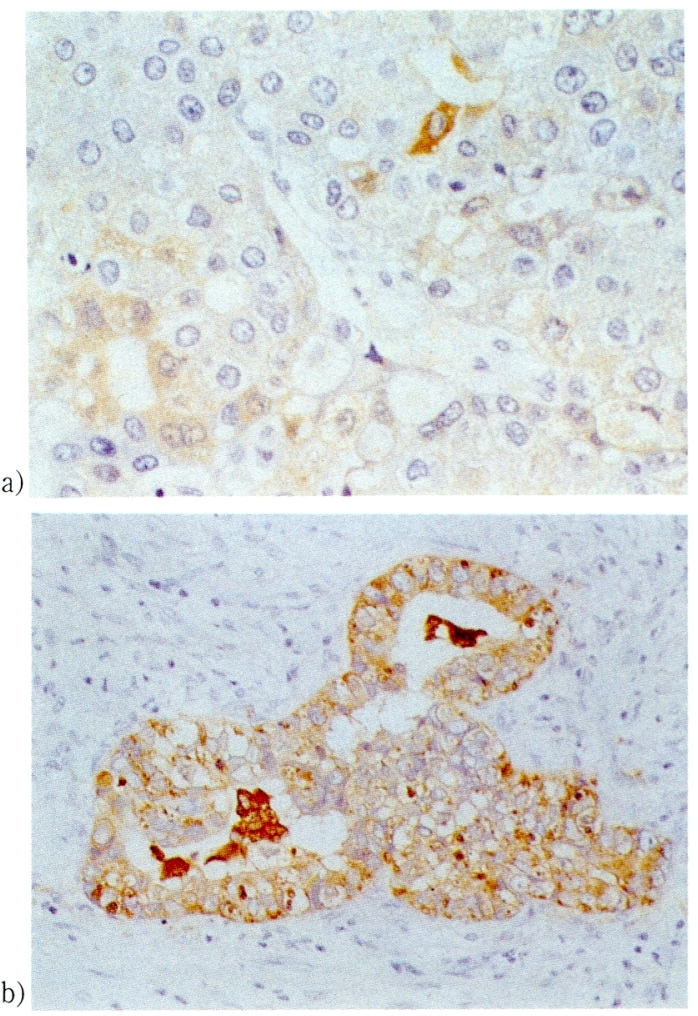

\section{考 察}

本症例は術前，術後を通じて肝臓，睪丸に異 常を認めず，術前高值を示した血清AFP值が腫 瘍摘出後正常化し，その後再上昇を認めていな いこと, さらには免疫組織化学的に腺癌細胞内 に抗AFP抗体陽性物質が証明されたことより， 
本腫瘍がAFPを産生していたと結論された。 AFP産生肺癌は現在までに本邦で20数例 ${ }^{1) ~ 9) ~ か ゙ ~}$ 報告されており，腫瘍マ一カ一の検索が盛んに なるにつれ増加してきた感がある。報告例は 1 例 ${ }^{3)}$ 除いて男性症例であり，通常の肺癌症例 と同じく60才から70才代に好発している。胸部 X 線写真の特徵としては，その多くが塊状影を 呈しており比較的大きな腫瘤で発見されている。 組織型としては腺癌が，中でも低分化腺癌が多 く, 次いで大細胞癌がその他の大部分を占め, 腺屏平上皮癌 ${ }^{4)}$, 小細胞癌5), 力ル千ノイド6)が各 1 例ずつ報告されている。血清AFP值は73ng/ $\mathrm{ml}^{7)} \sim 300 \mu \mathrm{g} / \mathrm{ml}^{8}$ 以上まで種々であるが，その 腫瘍の病期とはあまり関係がなかった。また他 の皿清腫瘍マーカーも陽性を示した報告は本例 の 如く $\mathrm{AFP}+\mathrm{CEA}$ を始 女, $\mathrm{AFP}+\mathrm{HCG}^{9)}$, $\mathrm{AFP}+\mathrm{CEA}+\mathrm{HCG}^{3)}$ な゙がある。そしてそれら の局在についての検索では, 各抗原は各々異な つた腫瘍細胞内に証明されている。なお本例の 妹 2 人が肺腺癌に罹患しており，その 1 例につ きAFPの検索をしたが陰性であった。

本例はまた上記低分化腺管型腺癌のほかに， 中分化扁平上皮癌が小葉間結合織を境に接して はいるが互いに独立して存在し，移行像を認め ない点から腺扁平上皮癌ではなく独立した 2 つ の腫瘍の衝突癌と判断した。衝突癌とは重複癌 の特殊な形と考えられ，Warren \& Gatesの重 複癌の定義 ${ }^{11}$ を満たし且つ互いの腫瘍が接して 存在する場合に用いられている名称である ${ }^{12)}$. わが国での肺衝突癌の報告は少なく，腺癌と線 維肉腫例 ${ }^{13)}$, 扁平上皮癌と小細胞癌例 ${ }^{12)}$ の 2 例 のみである。

本症例の臨床上の問題点としてはその術前評 価がある。本例は他院で一時腫瘍の縦隔進展と 呼吸機能の点から切除不能と判断され放射線治
療が開始されている。T因子の中で毛縦隔浸潤 の判定はCT, MRIなどの導入による診断精度 の向上にもかかわらず，なお困難を感ずること が多い。我々は人工的に気胸を作製し，その状 態で撮影を行う pneumothorax $\mathrm{CT}^{10)} よ り \mathrm{~T}$ 因子の評価を試みている。この方法による大動 脈浸潤の診断の正診率は高く, 本例でも癒着は あるものの浸潤のないことが pneumothorax CTにより判明し, 切除可能と診断し得た.

最後に，手術既往等による低肺機能症例にお

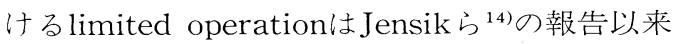
さかんに行われるようになってきたが，その適 応の多くは末梢発生のstage Iのcoin lesionとさ れている ${ }^{15)}$. 本例は70才という高齢で混合性換 気障害と最大換気率の低下を呈し, 心電四上も WPW症候群と負荷試験陽性所見が認められた ため腫瘍径が大きいにもかかわらず左上区域切 除術を施行した。切除標本にリンパ節転移はな く完全切除が成し得たと考えられた。 また術後 労作時呼吸困難を認めたことからも, 結果的に はこの切除範囲が限界であったと思われる。

\section{結 語}

$\mathrm{AFP}$ 産生低分化腺管型腺癌と中分化扁平上 皮癌から成る肺衝突癌の 1 例を経験したので報 告した。またその術前評価に抢いて, pneumothorax CTは大動脈浸潤の有無の診断に有用であ った。

稿を終えるに臨み, 同胞の肺癌症例の検索に御協力い ただいた国立栃木病院 佐藤正典先生, 立川相互病院 大石不二雄先生に感謝します。

本論文の要旨は, 第88回日本肺癌学会関東部会 (昭和 62年 3 月)に㧍いて発表した。

\section{文 献}

1）小泉 潔, 伊藤 広, 井田正博, 他：血清アル ファフェトプロテインの異常高值を呈した肺 大細胞未分化癌の 1 例. 癌の臨床, 25:11711175, 1979.
2) Yasunami. R., Hasimoto. Z., Ogura. T., et al. : Primary lung cancer producing alphafetoprotein: A case report. Cancer, 47 : 926-929, 1981. 
3) Yoshimoto. T., Higashino. K., Hada. T., et al. : A primary lung carcinoma producing alpha-fetoprotein, carcinoembryonic antigen, and human chorionic gonadotropine. Cancer, $60: 2744-2750,1987$.

4）亀井克彦, 楠本一生, 鈴木俊光, 他 : HCG, AFP の高值を示した肺癌の 1 剖検例. 肺癌, 26 ： 355, 1986.

5）東田有智, 上西豊基, 坂本和久, 他： $\alpha$-fetoprotein異常高值を示した肺原発の小細胞未分 化癌の 1 剖検例. 肺癌, $24: 763-767,1984$.

6）西村恭昌, 森川 進, 岡田英彦, 他: Alphafetoprotein産生をみた肺原発非定型カルチノ イドの 1例. 京都市立病院紀要, $4: 120-125$, 1984.

7) Tamura. T., Saijo. N., Shinkai. T., et al. : A case report of a three-year survivor with advanced non-small cell lung cancer producing alpha - fetoprotein. Jpn. J. Clin. Oncol., $16: 175-181,1986$.

8）早津正文, 盛 英機, 井沢和弘, 他：脳転移に よる右片麻瘒を主症状とした $\alpha$-フェトプロテイ ン産生肺癌の 1 例. 日内会誌, $72: 47-52$, 1983.

9) Miyake. M., Ito. M., Mitsuoka. A., et al.: Alpha
- fetoprotein and human chorionic gonadotropin-producing lung cancer. Cancer, $59: 227-232,1987$.

10）横井香平, 森 清志, 宮沢直人, 他: 肺癌の大 動脈浸潤の診断に応用した気胸 CT (Pneumothorax CT)について。 日本医放会誌, $47: 1198-1200,1987$.

11) Warren. S. and Gates. O. : Multiple primary malignant tumors. A survey of the literature and a statistical study. Am. J. Cancer, $16: 1358$ $-1414,1932$.

12）吉井新平, 広野達彦, 小池輝明, 他: 扁平上皮 癌と小細胞癌の肺衝突癌の一手術例. 肺癌, $25: 549-554,1985$.

13）加藤允義, 土器国光, 田中健蔵, 他：肺の衝突 腫瘍 (Collision Tumor) - 1 剖検例の報告と文 献的考察一。癌の臨床, $14: 879-883,1968$.

14) Jensik. R.J., Faber. L.P., Milloy. F.J., et al. : Segmental resection for lung cancer. J. Thorac. Cardiovasc. Surg., $66: 563-572$, 1973.

15) Hoffmann. T.H. and Ransdell. H.T. : Comparison of lobectomy and wedge resection for carcinoma of the lung. J. Thorac. Cardiovasc. Surg., $79: 211-217,1980$. 


\title{
A Case of Collision Tumor of Alpha-Fetoprotein Producing Adenocarcinoma and Squamous Cell Carcinoma of the Lung
}

\author{
Kohei Yokoi, Naoto Miyazawa, Kiyoshi Mori, Keigo Tominaga, \\ Keiko Suzuki* and Kayako Shimamura*
}

Division of Chest Disease and Pathology*,
Tochigi Cancer Center, Utunomiya, Japan

A 72-year-old man, who had received right thoracoplasty 35 years ago, was admitted with a large tumor of the left lung. Although the tumor appeared in contact with the aortic arch on plain chest films, a pneumothorax CT scan revealed it was not invasive to the aortic wall. A partial resection of the superior segment from the left upper lobe was performed. The preoperative serum level of AFP was $5107 \mathrm{ng} / \mathrm{ml}$ and that of CEA was $12.5 \mathrm{ng} / \mathrm{ml}$, but decreased to normal levels 34 days and 8 days after the operation, respectively. The tumor was a "collision tumor" consisting of poorly differentiated tubular adenocarcinoma and moderately differentiated squamous cell carcinoma. Immunohistochemical study revealed that only adenocarcinoma cells were stained with anti-AFP and CEA serum. 